OLIVEIRA, FL; VENTURIM, CHP; SILVA, DMN; QUARESMA, MAL; DALVI, LP. 2018. Mulches for yacon cultivation. Horticultura Brasileira 36: 389-394. DOI - http://dx.doi.org/10.1590/S0102-053620180317

\title{
Mulches for yacon cultivation
}

\section{Fabio Luiz Oliveira; Cristiano Henrique P Venturim; Diego Mathias N Silva; Mateus Augusto L Quaresma; Leandro P Dalvi ${ }^{1}$}

${ }^{1}$ Universidade Federal do Espírito Santo (UFES), Alegre-ES, Brazil; fabio.oliveira.2@ufes.br; cristianoventurim@hotmail.com; diegoufvjm@ yahoo.com.br; mateusveio@hotmail.com; leandro.dalvi@ufes.br

\begin{abstract}
In Brazil, studies on commercial exploitation of yacon are still scarce. A growing interest in this vegetable has demanded some researches on this crop cultivation management, though. Considering that yacon has a long cycle, which exposes the soil, studies on mulch management will be of great value. We used a randomized complete block design, with five replicates, under different soil mulches for yacon cultivation: two plastic film covers (black and double-sided), four mulches (corn husk, coffee husk in three levels), and the control (bare soil). Plastic mulch can be used for yacon cultivation, considering that the double sided plastic provides greater production of total roots; however, the same yield of the most valued roots was obtained using black plastic. The second highest total productivity and the highest commercial yield in the most valued root classes were obtained using $50 \mathrm{~L} \mathrm{~m}^{-2}$ of coffee husk as mulch, representing a good alternative for farmers.
\end{abstract}

Keywords: Smallanthus sonchifolius, tuberous root, yield, soil protection.

\section{RESUMO}

\section{Coberturas de solo para o cultivo do yacon}

O crescente interesse pela exploração comercial do yacon tem demandado a geração de conhecimentos sobre o seu manejo, principalmente no Brasil, onde são escassas as pesquisas a respeito. Sendo essa uma hortaliça de ciclo longo, com exposição do solo, estudos sobre o manejo da cobertura são de grande valia para o sucesso do seu cultivo. Assim, realizou-se experimento em delineamento experimental de blocos ao acaso, com cinco repetições, avaliando diferentes coberturas de solo, sendo duas coberturas com filme plástico (preto e dupla face) e quatro coberturas mortas (palha de milho; casca de café em três níveis), além da testemunha (solo descoberto). A cobertura de solo no cultivo do yacon pode ser feita com o uso do plástico: plástico duplo face propicia maior produção total de raízes, no entanto, com os mesmos rendimentos que o plástico preto, para raízes nas classes mais valorizadas no mercado. $\mathrm{O}$ uso da cobertura morta com $50 \mathrm{~L}$ $\mathrm{m}^{-2}$ de casca de café promoveu a segunda melhor produtividade total e o melhor rendimento em raízes nas classes de melhor valorização comercial, representando uma alternativa ao agricultor.

Palavras-chave: Smallanthus sonchifolius, raiz tuberosa, rendimento, proteção de solo.

\section{Received on February 15, 2017; accepted on February 13, 2018}

$\mathrm{F}$ ast paced life has caused serious harm to human health; that is why people have been seeking healthier lifestyles. Changing eating habit is one of the main goals to achieve, related to health benefits, targeting both sensory and nutritional quality (Barcellos et al., 2009). In this context, some functional foods, which present both nutritional and nutraceutical values, had appeared on the market (Zeraik et al., 2010).

A functional food that has attracted the interest of population is yacon root (Smallanthus sonchifolius), due to presence of bioactive elements in its composition, such as inulin-type fructose and fructo-oligosaccharides which provides several benefits to health (Gusso et al., 2015).
Its consumption has provided well-known benefits such as immune stimulatory effect (Tostes et al., 2014), prebiotics (Campos et al., 2012) and protection against colon cancer (Moura et al., 2012), besides acting in reduction of serum lipids (Habib et al., 2011), in intestinal regularization (Lobo et al., 2011), and in modulation of fasting insulin (Genta et al., 2010), and it also has provided control of chronic diseases like diabetes (Oliveira et al., 2013b).

Recent studies have further stimulated the consumption of yacon, increasing interest on this crop, especially food and pharmaceutical industries. In Brazil, the earliest cultivation took place in the countryside of São Paulo State, in the late 1990s. Yacon has been grown recently on the mountainsides of Rio de Janeiro, Santa Catarina and Espírito Santo States (Oliveira et al., 2013a). Nevertheless, to guarantee success of commercial production of yacon, technological knowledge on this management is necessary. This information is still scarce, though, mainly in Brazil.

Appropriate soil management is crucial to explore yacon as vegetable, considering that this crop presents a slow initial growing, it is able to take up to 60 days to emerge, and a long cycle, from 7 to 11 months (Silva, 2015), which allows soil exposure.

One good alternative to protect soil would be the use of mulch, which is already popular for growing vegetables, 
since it also contributes to improve production and quality of products. Some studies report the advantages of using mulch in growing onions (Santos et al., 2012), carrot (Resende et al., 2005) and beet (Sediyama et al., 2011), crops that, such as yacon, accumulate reserves in underground organs.

Several materials can be used in order to provide soil cover. For vegetable production, plastic films are more commonly used, as well as plantorigin materials, such as wood chips, bark and straw in general (Sediyama et al., 2011; Santos et al., 2012), including living mulches (Silva et al., 2013).

Nevertheless, the success with the use of mulch depends on information about appropriated management in each environment and about the growing crop. Thus, with an increase and recent commercial exploitation of yacon, studying soil mulch management is pretty important for its cultivation.

The aim of this study was to evaluate growing and production of yacon, cultivated under different mulch types.

\section{MATERIAL AND METHODS}

The experiment was carried out from April to November, 2015 in a commercial growing area, in the municipality of Ibatiba-ES (20'14'02"S; 4130'38'W; $880 \mathrm{~m}$ altitude). Temperature and rainfall data were collected at the closest automatic weather station $\left(20^{\circ} 21^{\prime} 25^{\prime \prime} \mathrm{S} ; 41^{\circ} 33^{\prime} 25^{\prime \prime} \mathrm{W} ; 758 \mathrm{~m}\right.$ altitude), located in the municipality of Iúna-ES. Average temperatures $\left({ }^{\circ} \mathrm{C}\right)$, from April to November were respectively: $23 ; 19.8 ; 19.2 ; 19.3 ; 20.1$; 23.4; 24.5 and 26.3. Average rainfall (mm), from April to November were respectively: $76.4 ; 108.9 ; 35.3 ; 5.1 ; 0.0$; 48.9; 145.8 and 25.7.

Soil was classified as Red-Yellow Latosol, medium texture (Embrapa, 2014). Sample was collected $(0-20 \mathrm{~cm}$ layer depth) and submitted to chemical and physical analyses, presenting the following result: $\mathrm{pH}_{\text {water }}=6.15 ; \mathrm{P}=12.05$ $\mathrm{mg} \mathrm{dm}{ }^{-3} ; \mathrm{K}=48 \mathrm{mg} \mathrm{dm}^{-3} ; \mathrm{Ca}=2.57$ cmolc dm${ }^{-3} ; \mathrm{Mg}=0.96 \mathrm{cmolc} \mathrm{dm}^{-3} ; \mathrm{Al}=$ $0.0 \mathrm{cmolc} \mathrm{dm}^{-3}$; Sum of bases $=3.69$ cmolc dm${ }^{-3}$; effective $\mathrm{CEC}=3,69 \mathrm{cmolc}$ $\mathrm{dm}^{-3}$; bases saturation $=43.96 \%$; Sand $=$ $65 \%$; Silt $=5 \%$; Clay $=30 \%$.

The experimental design was randomized blocks, with five replicates and seven treatments: two plastic film covers, one black and another double sided (black/white); one covered with corn straw $\left(30 \mathrm{~L} \mathrm{~m}^{-2}\right)$; three covered with coffee husk under different levels (25, 50 and $75 \mathrm{~L} \mathrm{~m}^{-2}$, considered levels 1,2 and 3, respectively); and one under bare soil (control).

Each experimental plot consisted of 4 planting rows with 7 plants, spaced 1.0 between rows and 0.5 between plants. The authors used two central rows as useful area, except the border plants of each row.

Soil was covered with mulching polypropylene (MPP), 25 micrometers thickness, [ElectroPlastic SA, MPP-P (black) and MPP-P\&B (black/white)]; MPP-P\&B film offers a black and a white side, the black side was in direct contact with soil. Soil was plowed at 30 $\mathrm{cm}$ followed by harrowing. After this soil preparation, the film was stretched over planting lines, covering $80 \mathrm{~cm}$ band of soil and then, pits were opened to plant seedlings.

Corn straw mulch was obtained from what was left of mechanical treshing (spike straw and ground corncob), which was performed 50 days before. During this period, straw was exposed to weather conditions. Coffee husk was obtained from Arabica coffee processing, done 270 days before its use, and was also exposed to weather conditions.

Yacon seedlings were formed through herbaceous stakes, measuring approximately $10-15 \mathrm{~cm}$ from adult plants. The stakes were put in $600-\mathrm{mL}$ volume plastic bags (traditionally used for coffee seedling production), being irrigated daily. After 60 days, seedlings were ready to be planted, being selected the uniform sized.

Top-dressing fertilization was performed 50 days after transplanting, using $180 \mathrm{~g}$ of tanned bovine manure per plant. Bovine manure showed the following nutrients: $10.1 \mathrm{~g} \mathrm{~kg}^{-1} \mathrm{~N} ; 3.96$ $\mathrm{g} \mathrm{kg}^{-1} \mathrm{P} ; 7.59 \mathrm{~g} \mathrm{~kg}^{-1} \mathrm{~K} ; 4.54 \mathrm{~g} \mathrm{~kg}^{-1} \mathrm{Ca}$ and $2.14 \mathrm{~g} \mathrm{~kg}^{-1} \mathrm{Mg}$. Additional irrigation was not done in the area.

During crop development, data were obtained at $60,90,120,150,180$ and 210 days after transplanting (DAP). The authors evaluated: plant height (greater stem), number of leaves, number of stems, shoot dry matter accumulation, rhizophores and roots.

Cycle closing date was established at $210 \mathrm{DAP}$, due to flowering; then productivity was evaluated. We evaluated total productivity of fresh tuberous roots and productivities per class: $1 \mathrm{~A}(<130 \mathrm{~g}) ; 2 \mathrm{~A}(130$ to 250 g); 3A (>250 g) (CEAGESP, 2016). Physico-chemical analyses of tuberous roots were also performed, determining moisture contents, soluble solids, $\mathrm{pH}$ and ashes (Instituto Adolfo Lutz, 2008).

Data were submitted to analysis of variance using ASSISTAT program (Silva \& Azevedo, 2006). Average of original data related to height, number of leaves and number of stems were adjusted, based on simple linear regression, to different models, considering time as an independent variable. The authors chosed $2^{\text {nd }}$ degree polynomial model since it represents higher coefficient of determination $\left(\mathrm{R}^{2}\right)$ and significance of all regression coefficients (Table 1). The other data were submitted to Scott-Knott tests at $5 \%$ probability.

\section{RESULTS AND DISCUSSION}

Yacon vegetative development was influenced by soil covers. For all the evaluated variables (plant height, number of stems and number of leaves), the authors noticed practically no difference among treatments up to 120 days after transplanting. From 150 days on some difference in plants was noticed; this difference became clearer from 180 days on, mainly for coffee straw mulch, at levels 2 and 3 (50 and $75 \mathrm{~L} \mathrm{~m}^{-2}$ ) and two plastic mulches (black and double sided), considering that, using these covers, higher heights, larger number of stems and leaves were observed (Figure 1).

Overall, the authors observed that yacon plants showed a small difference 
in number of leaves from 60 up to 150 days, probably due to strong dry weather in this period (from June to September, 2015). Average rainfall was $22.3 \mathrm{~mm} /$ month, considering that during July, the rainfall was only $5 \mathrm{~mm}$ and in August no rain at all. From this date up to the end of the cycle, the authors observed an increase in number of leaves, and that soil covers, mainly the coffee straw mulch at levels 2 and 3 and the two plastic mulches (black and double sided), promoted larger numbers (Figure 1).

Yacon plants grown using coffee straw mulches (levels 2 and 3) and two plastic covers (black and double sided) showed higher plants with greater number of stems (on average $100 \%$ ), as well as with greater number of leaves $(45 \%)$, compared to the ones which were grown in bare soil. This can be a result of water storage in covered soil, since according to Fernández et al. (2006),

Table 1. Coefficients of the second degree polynomial model $\left[\mathrm{Y}=\mathrm{a}+\mathrm{bt}+\mathrm{ct}^{2}\right]$ adjusted to height, number of stems and leaves of yacon plants grown under different soil mulches. Ibatiba, UFES, 2015.

\begin{tabular}{|c|c|c|c|c|c|}
\hline Traits & Mulches & $\mathbf{a}$ & $\mathbf{b}$ & $\mathbf{c}$ & $\mathbf{R}^{2}$ \\
\hline \multirow{7}{*}{ 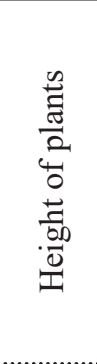 } & Black plastic film & 20.35 & -0.28 & $3.53 \mathrm{e}-3$ & 98.58 \\
\hline & Double-sided plastic film & 21.64 & -0.29 & $3.53 \mathrm{e}-3$ & 99.21 \\
\hline & Corn straw & 32.09 & -0.43 & $3.11 \mathrm{e}-3$ & 99.70 \\
\hline & Coffee husk $1^{1}$ & 22.27 & -0.22 & $2.43 \mathrm{e}-3$ & 99.11 \\
\hline & Coffee husk $2^{2}$ & 15.72 & -0.19 & $3.61 \mathrm{e}-3$ & 99.14 \\
\hline & Coffe husk $3^{3}$ & 37.63 & -0.57 & $4.61 \mathrm{e}-3$ & 99.73 \\
\hline & Bare soil & 27.49 & -0.31 & $2.04 \mathrm{e}-3$ & 99.61 \\
\hline \multirow{7}{*}{ 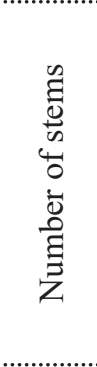 } & Black plastic film & 1.46 & -0.01 & $8.10 \mathrm{e}-5$ & 99.51 \\
\hline & Double-sided plastic film & 1.54 & $-8.23 e-3$ & $6.60 \mathrm{e}-5$ & 99.94 \\
\hline & Corn straw & 1.61 & -0.01 & $5.60 \mathrm{e}-5$ & 93.00 \\
\hline & Coffee husk $1^{1}$ & 1.96 & -0.02 & $9.40 \mathrm{e}-5$ & 98.38 \\
\hline & Coffee husk $2^{2}$ & 2.51 & -0.03 & $1.43 \mathrm{e}-4$ & 97.67 \\
\hline & Coffe husk $3^{3}$ & 1.92 & -0.02 & $1.13 \mathrm{e}-4$ & 97.41 \\
\hline & Bare soil & 0.89 & $2.71 \mathrm{e}-3$ & $1.00 \mathrm{e}-6$ & 95.79 \\
\hline \multirow{7}{*}{ 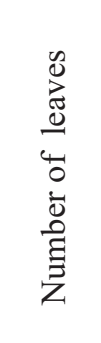 } & Black plastic film & 22.10 & -0.29 & $1.95 \mathrm{e}-3$ & 98.08 \\
\hline & Double-sided plastic film & 12.83 & -0.05 & $9.09 \mathrm{e}-4$ & 99.96 \\
\hline & Corn straw & 14.25 & -0.10 & $6.67 \mathrm{e}-4$ & 92.67 \\
\hline & Coffee husk $1^{1}$ & 16.17 & -0.12 & $8.69 \mathrm{e}-4$ & 98.49 \\
\hline & Coffee husk $2^{2}$ & 25.05 & -0.29 & $1.96 \mathrm{e}-3$ & 98.37 \\
\hline & Coffe husk $3^{3}$ & 30.62 & -0.41 & $2.44 \mathrm{e}-3$ & 95.67 \\
\hline & Bare soil & 1.42 & 0.10 & $-1.14 \mathrm{e}-4$ & 96.98 \\
\hline
\end{tabular}

${ }^{1}$ Volume of $25 \mathrm{~L} \mathrm{~m}^{-2} ;{ }^{2}$ Volume of $50 \mathrm{~L} \mathrm{~m}^{-2} ;{ }^{3}$ Volume of $75 \mathrm{~L} \mathrm{~m}^{-2}$. water availability is determinant for growth and productivity yield of yacon. Thus, all agricultural practice which benefits this availability may result in gains in this crop.

Generally, heights observed in plants with higher growth, were a little shorter, 110 to $130 \mathrm{~cm}$, than the ones observed by Silva (2015), which measured around $170 \mathrm{~cm}$, at 270 days after planting, being planted at the same time and in the same region. The same situation was observed for number of stems, from 2.5 to 3.5 , from plants with higher growth, whereas Silva (2015) reported from 6 to 10 stems per plant.

This behavior may be related to propagation material, since in this study, seedlings from herbaceous stakes were used, whereas Silva (2015) used seedlings from rhizophores. According to Robles (2002), plants obtained from rhizophores showed better growth, mainly in initial phase, since they take

ya yacon propagation (Robles, 2002). Thus, their higher production could allow not only increase farmers' autonomy for future plantations, but also increase their commercial value, both as propagation material and as source of FOS, considering that rhizophores have large amounts of this oligosaccharide (Vilhena et al., 2000).

The results show that the use of a good mulch benefits yacon development. This behavior has been observed in several crops, being related to a greater water and nutrient conservation in soil, protection against erosion, increase in microbial activity and photosynthesis, lower thermal amplitude and greater control of spontaneous vegetation (Resende et al., 2005; Santos et al., 2011).

The best development of yacon observed with the use of soil covers resulted in higher fresh root productivities. The authors highlighted that higher total productivity was observed using double-sided plastic film, followed by coffee husk mulch level 2 and then coffee husk cover level 3 and with black plastic film, considering these last ones statistically 
Table 2. Dry mass of shoots, rhizophores and roots of yacon plants grown under different mulches. Ibatiba, UFES, 2015.

\begin{tabular}{lccc}
\hline Mulch & $\begin{array}{c}\text { Shoot dry mass } \\
(\mathbf{g})\end{array}$ & $\begin{array}{c}\text { Rhizophore dry } \\
\text { mass }(\mathbf{g})\end{array}$ & $\begin{array}{c}\text { Root dry mass } \\
(\mathbf{g})\end{array}$ \\
\hline Black plastic film & $1155.56 \mathrm{~b}$ & $568.83 \mathrm{~b}$ & $718.82 \mathrm{a}$ \\
Double-sided plastic film & $1163.68 \mathrm{~b}$ & $571.06 \mathrm{~b}$ & $877.55 \mathrm{a}$ \\
Corn straw & $742.84 \mathrm{c}$ & $528.49 \mathrm{~b}$ & $484.28 \mathrm{~b}$ \\
Coffee husk 1 $^{1}$ & $855.12 \mathrm{c}$ & $585.42 \mathrm{~b}$ & $528.96 \mathrm{~b}$ \\
Coffee husk 2 $^{2}$ & $1548.12 \mathrm{a}$ & $762.44 \mathrm{a}$ & $817.15 \mathrm{a}$ \\
Coffe husk 3 $^{3}$ & $1447.60 \mathrm{a}$ & $797.19 \mathrm{a}$ & $671.46 \mathrm{a}$ \\
Bare soil & $327.60 \mathrm{~d}$ & $384.88 \mathrm{c}$ & $209.43 \mathrm{c}$ \\
\hline CV $(\%)$ & 26.51 & 19.98 & 25.54 \\
\hline
\end{tabular}

${ }^{1}$ Volume of $25 \mathrm{~L} \mathrm{~m}^{-2} ;{ }^{2}$ Volume of $50 \mathrm{~L} \mathrm{~m}^{-2} ;{ }^{3}$ Volume of $75 \mathrm{~L} \mathrm{~m}^{-2}$. Averages followed by same letter in the column did not differ significantly from each other, Scott-Knott, $\mathrm{p}<0.05$.

the same (Table 3).

Productivities observed were lower when compared with the ones obtained by Silva (2015), who also planted in October in the same region (average of $97.5 \mathrm{tha}^{-1}$ ). This difference is associated, mainly, to the water deficit from June to November, 2015. The exception within these 6 months was October, registering $145.8 \mathrm{~mm}$ and to propagative material used, herbaceous stakes, which showed lower growth, when compared with the plants from rhizophores, resulting in lower harvest index, as cited by Robles (2002).

Overall, yacon productivity is very varied. Some authors report that this is due to the influence of the propagative material, as well as to fertilization, spacing, soil and climatic conditions and different planting times (Robles, 2002; Kruger, 2003; Silva, 2015).
In São Paulo State, productivities from 30 and $62.5 \mathrm{t} \mathrm{ha}^{-1}$ were reported (Robles, 2002; Kruger, 2003; Oliveira \& Nishimoto, 2004). In Espírito Santo, Silva (2015) obtained productivities from 60.6 to $97.5 \mathrm{t} \mathrm{ha}^{-1}$, in the municipalities of Alegre and Ibatiba, respectively, planting in October.

Mulches also influenced yacon fresh root classes. The authors noticed that mulching with coffee husk level 2 was the one which showed higher productivity of roots class $3 \mathrm{~A}$, followed by the mulch with two types of plastic films and then by the mulch with coffee husk level 3. For class 2A, the authors observed that these four mulches showed the same productivity, statistically. For class 1A, higher productivity was noticed using mulch with double-sided plastic film (Table 3).

However, greater economic profitability, related to best prices on the market, is obtained producing classes $3 \mathrm{~A}$ and $2 \mathrm{~A}$, and considering this fact, the mulch with coffee husk level 2 stood out since it presented higher volume even considering the sum of these two classes $\left(20.93 \mathrm{tha}^{-1}\right)$, which represented a yield of $73.8 \%$ of roots. The mulches with double-sided plastic film also provided similar values (19.61 t ha $\left.^{-1}\right)$, with lower yield, though (61.8\%). That means that great part of roots did not meet market needs, which represents economic losses.

Besides gains in root quantity, mulches also provided a small change in soluble solid contents ( $\left({ }^{\circ} \mathrm{Brix}\right)$ in roots. The mulches with double-sided plastic film, corn straw and coffee husk level 3 showed higher ${ }^{\circ}$ Brix values (Table 3 ).

Higher soluble solid contents promoted by these mulches are interesting to yacon roots, since this index is expected to be used to verify the quality of roots, mainly due to the habit of eating raw roots; considering that, the higher the soluble solids content the greater the sweetness and the quality, and, therefore, consumers' greater interest (Gusso et al., 2015).

Generally, soluble solid contents were between 8.6 and $11.7^{\circ}$ Brix, which are values close to the ones reported by Silva (2015), around $12^{\circ}$ Brix, and Lago et al. (2011), $8.0^{\circ}$ Brix.

Other chemico-physical variable analyses did not show significant differences related to the use of different mulches, considering that $\mathrm{pH}$ values ranged from 5.94 to 6.29 , corroborating

Table 3. Total productivity and productivity per class, and soluble solids content of yacon roots grown under different mulches. Ibatiba, UFES, 2015.

\begin{tabular}{lccccc}
\hline Mulch & $\begin{array}{c}\text { Total productivity } \\
\left(\mathbf{t ~ h a}^{-1}\right)\end{array}$ & $\begin{array}{c}\text { Roots (3A) } \\
\left(\mathbf{t ~ h a}^{-1}\right)\end{array}$ & $\begin{array}{c}\text { Roots (2A) } \\
\left(\mathbf{t ~ h a}^{-1}\right)\end{array}$ & $\begin{array}{c}\text { Roots (1A) } \\
(\mathbf{t ~ h a - 1})\end{array}$ & $\begin{array}{c}\text { Soluble solids } \\
\left({ }^{\mathbf{0}} \mathbf{B r i x}\right)\end{array}$ \\
\hline Black plastic film & $24.26 \mathrm{c}$ & $7.46 \mathrm{~b}$ & $10.23 \mathrm{a}$ & $6.57 \mathrm{~b}$ & $10.06 \mathrm{~b}$ \\
Double-sided plastic film & $31.71 \mathrm{a}$ & $7.01 \mathrm{~b}$ & $12.60 \mathrm{a}$ & $12.11 \mathrm{a}$ & $11.70 \mathrm{a}$ \\
Corn straw & $15.30 \mathrm{~d}$ & $2.25 \mathrm{~d}$ & $5.52 \mathrm{~b}$ & $7.53 \mathrm{~b}$ & $11.00 \mathrm{a}$ \\
Coffee husk 1 $^{1}$ & $16.67 \mathrm{~d}$ & $2.83 \mathrm{~d}$ & $6.95 \mathrm{~b}$ & $6.89 \mathrm{~b}$ & $9.74 \mathrm{~b}$ \\
Coffee husk 2 $^{2}$ & $28.35 \mathrm{~b}$ & $9.08 \mathrm{a}$ & $11.85 \mathrm{a}$ & $7.42 \mathrm{~b}$ & $9.80 \mathrm{~b}$ \\
Coffe husk 3 $^{3}$ & $23.09 \mathrm{c}$ & $4.84 \mathrm{c}$ & $12.01 \mathrm{a}$ & $6.24 \mathrm{~b}$ & $10.74 \mathrm{a}$ \\
Bare soil & $6.71 \mathrm{e}$ & $1.00 \mathrm{e}$ & $3.10 \mathrm{c}$ & $2.60 \mathrm{c}$ & $8.60 \mathrm{~b}$ \\
\hline CV $(\%)$ & 11.78 & 22.74 & 15.64 & 17.9 & 9.1 \\
\hline
\end{tabular}

${ }^{1}$ Volume of $25 \mathrm{~L} \mathrm{~m}^{-2} ;{ }^{2}$ Volume of $50 \mathrm{~L} \mathrm{~m}^{-2} ;{ }^{3}$ Volume of $75 \mathrm{~L} \mathrm{~m}^{-2}$. Averages followed by same letter in the column did not differ significantly from each other, Scott-Knott, $\mathrm{p}<0.05$. 


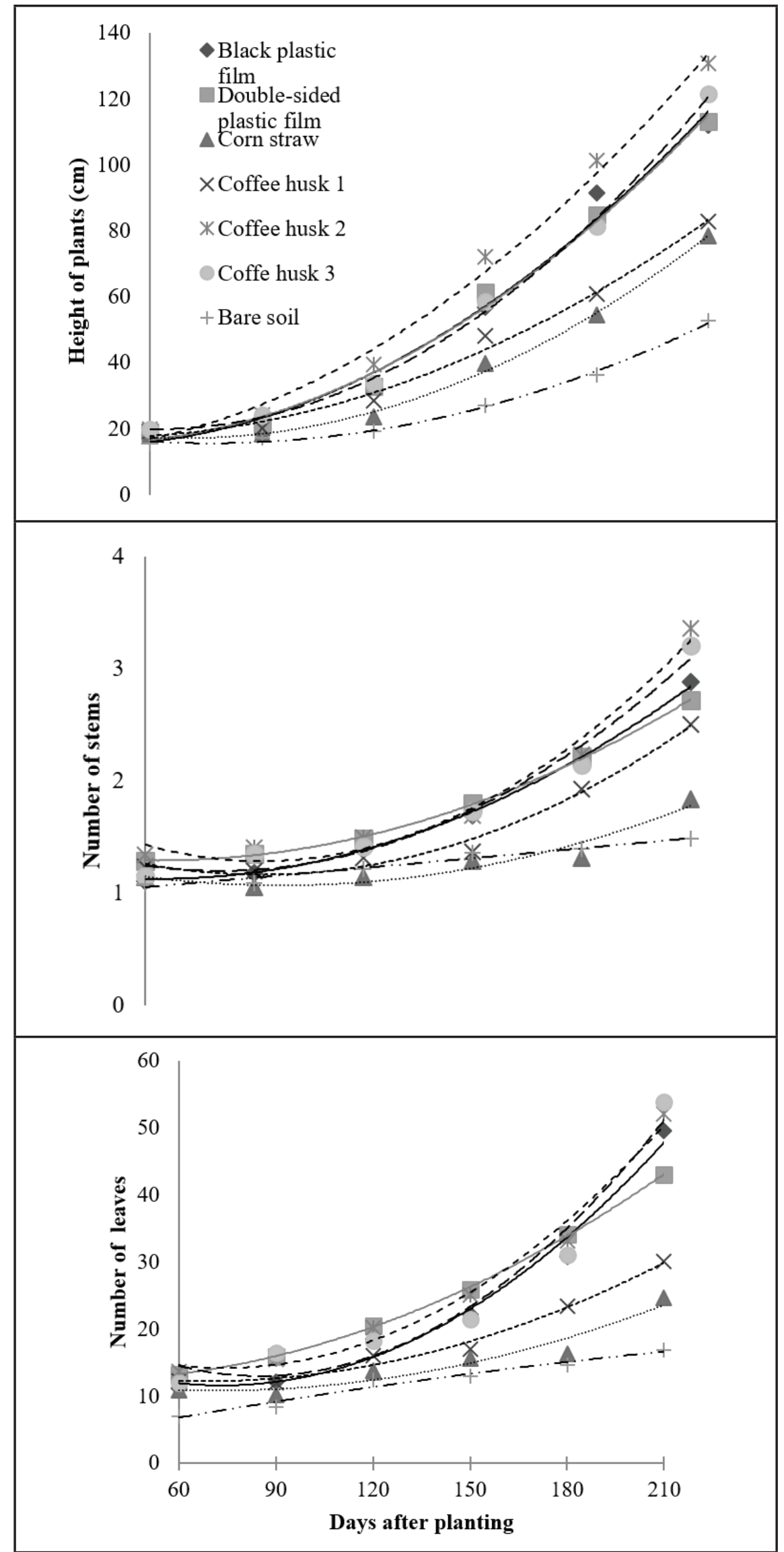

Figure 1. Height, number of stems and number of leaves, grown under different mulches. Ibatiba, ES. 2015. the report by Castro et al. (2013) and Silva (2015), who observed $\mathrm{pH}$ values ranging from 6.0 to 6.9. Moisture contents of yacon roots, in natura (moisture basis) were between 87.76 and $89.67 \%$. These results corroborate studies carried out by Prati et al. (2009), Pereira (2009) and Silva (2015), reporting $80.70,89.74$ and $91.2 \%$, respectively. Ash contents were between 0.71 and 0.92 , close to values reported by Pereira (2009), $0.9 \%$, and superior to the ones reported by Silva (2015) from 0.17 to $0.48 \%$.

Given the above, the authors concluded that yacon plants are benefited by mulches, showing better vegetative and productive development, standing out the possibility of using soil cover technology. The double-sided mulch is the one which promotes higher total production volumes, showing the same yields when using the black plastic, for production of roots in the most valued classes, though.

Among the mulches which provided better performance of this vegetable, the coffee husk mulch stands out, mainly the one with $50 \mathrm{~L} \mathrm{~m}^{-2}$, besides being lower volume (comparing with $75 \mathrm{~L}$ $\mathrm{m}^{-2}$ ), making handling easier, promoted the second best total productivity and higher yield of roots in the most valued classes.

This fact allows the use of this mulch in several productive systems, including organics, resulting in a good return with lower investment, mainly in regions where coffee is produced, and its husk is an abundant and available resource.

In short, soil cover for yacon cultivation can be done using plastic, considering that the double-sided plastic provides higher total production volumes of roots and higher gains in soluble solids, with the same yields the black plastic provides for roots in the most valued classes.

Mulch using $50 \mathrm{~L} \mathrm{~m}^{-2}$ of coffee husk promotes the second best total productivity and better yields for roots in the most valued classes, representing a good alternative to the farmer who does not want to use agricultural plastics.

\section{ACKNOWLEDGEMENTS}

To CNPq (The National Council 
for Scientific and Technological Development) and FAPES (Research Support Foundation) for financial support to this research. To FAPES for capixaba researcher scholarship to the first authors.

\section{REFERENCES}

BARCELLOS, MD; AGUIAR, LK; FERREIRA, GC; VIEIRA, LM. 2009. Willingness to try innovative food products: A comparison between British and Brazilian consumers. Brazilian Administration Review 6: 50-61.

CAMPOS, D; BETALLELUZ-PALLARDEL, I; CHIRINOS, R; AGUILAR-GALVEZ, A; NORATTO, G; PEDRESCHI, R. 2012. Prebiotic effects of yacon (Smallanthus sonchifolius Poepp. \& Endl), a source of fructooligosaccharides and phenolic compounds with antioxidant activity. Food Chemistry 135: 1592-1599.

CASTRO, A; CÉSPEDES, G; CARBALLO, S; BERGENSTÅHL, B; TORNBERG, E. 2013. Dietary fiber, fructooligosaccharides, and physicochemical properties of homogenized aqueous suspensions of yacon (Smallanthus sonchifolius). Food Research International 50: 392-400.

CEAGESP, Companhia de Entrepostos e Armazéns Gerais de São Paulo. 2016. Classificação de batata Yacon.. São Paulo: CEAGESP, 11p (Boletim do Centro de Qualidade, Pesquisa e Desenvolvimento, 4).

EMBRAPA, Empresa Brasileira de Pesquisa Agropecuaria. 2014. Sistema Brasileiro de Classificação de Solos. 4.ed. Rio de Janeiro: Embrapa Solos. 377p

FERNÁNDEZ, EC; VIEHMANNOVA, I; LACHMAN, J; MILELLA, L. 2006. Yacon [Smallanthus sonchifolius (Poeppig \& Endlicher) H. Robinson]: a new crop in the Central Europe. Plant Soil and Environment 52: 564-570.

GENTA, SB; CABRERA, WM; MERCADO, MI; GRAU, A; CATALÁN, CA; SÁNCHEZ, SS. 2010. Hypoglycemic activity of leaf organic extracts from Smallanthus sonchifolius: constituents of the most active fractions. Chemico-Biological Interactions 185: 143 152.

GUSSO, AP; MATTANNA, P; RICHARDS, N. 2015. Yacon: benefícios à saúde e aplicações tecnológicas. Ciência Rural 45: 912-919.
HABIB, NC; HONORÉ, SM; GENTA, SB; SÁNCHEZ, SS. 2011. Hypolipidemic effect of Smallanthus sonchifolius (yacon) roots on diabetic rats: Biochemical approach. ChemicoBiological Interactions 194: 31-39.

IAL, Instituto Adolfo Lutz. 2008. Métodos físico-químicos para análise de alimentos. 4 ed. ( $1^{\mathrm{a}}$ ed. digital). São Paulo: IAL, 1002p.

KRUGER, FGQ. 2003. Adubação mineral, orgânica e biodinâmica de yacon (Polymnia sonchifolia Poep \& Endl): rendimento, qualidade e armazenamento. Botucatu: Unesp. 72p (Ph.D. thesis).

LAGO, CC; BERNSTEIN, A; BRANDELLI, A; NOREÑA, CZ. 2011. Characterization of powdered yacon (Smallanthus sonchifolius) juice and pulp. Food and Bioprocess Technology 5: 2183-2191.

LOBO, AR; COCATO, ML; BORELLI, P; GAIEVSKI, EHS; CRISMA, AR; NAKAJIMA, K; NAKANO, EY; COLLI, C. 2011. Iron bioavailability from ferric pyrophosphate in rats fed with fructan containing yacon (Smallanthus sonchifolius) flour. Food Chemistry 126: 885-891.

MOURA, NA; CAETANO, BFR; SIVIERI, K; URBANO, LH; CABELLO, C; RODRIGUES, MAM; BARBISAN, LF. 2012. Protective effects of yacon (Smallanthus sonchifolius) intake on experimental colon carcinogenesis. Food and Chemical Toxicology 50: 2902-2910.

OLIVEIRA, FL; SILVA, DMN; QUARESMA, MAL. 2013a. Yacon: potencial como hortaliça. In: Tópicos especiais em Produção Vegetal, $I V$. 1ed. Alegre-ES: CAUFES, p. 502-529.

OLIVEIRA, GO; BRAGA, CP; FERNANDES, AAH. 2013b. Improvement of biochemical parameters in type 1 diabetic rats after the roots aqueous extract of yacon (Smallanthus sonchifolius). Food and Chemical Toxicology 59: 256-260.

OLIVEIRA, MA; NISHIMOTO, EK. 2004. Avaliação do desenvolvimento de plantas de yacon (Polymnia sonchifolia) e caracterização dos carboidratos de reservas em HPLC. Brazilian Journal of Food Technology 7: 215-220.

-PEREIRA, RACB. 2009. Extração e utilização de frutanos de yacon (Polymnia sonchifolia) na funcionalização de alimentos. Botucatu: Unesp. 154p (Ph.D. thesis).

PRATI, P; BERBARI, SAG; PACHECO, MTB; SILVA, MG; NACAZUME, N. 2009. Estabilidade dos componentes funcionais de geleia de yacon, goiaba e acerola, sem adição de açúcares. Brazilian Journal of Food
Technology 12: 285-294.

RESENDE, FV; SOUZA, LS; OLIVEIRA, PSR; GUALBERTO, R. 2005. Uso de cobertura morta vegetal no controle da umidade e temperatura do solo, na incidência de plantas invasoras e na produção da cenoura em cultivo de verão. Ciência e Agrotecnologia 29: 100-105.

ROBLES, JEA. 2002. Desenvolvimento de yacón (Polymnia sonchifolia Poep. \&Endl.) a partir de rizóforos e de gemas axilares, em diferentes espaçamentos. Botucatu: Unesp. 102p (Ph.D. thesis).

SANTOS, CAB; ZANDONÁ, SR; ESPINDOLA, JAA; GUERRA, JGM; RIBEIRO, RLD. 2011. Efeito de coberturas mortas vegetais sobre o desempenho da cenoura em cultivo orgânico. Horticultura Brasileira 29: 103-107.

SANTOS, SS; ESPÍNDOLA, JAA; GUERRA, JGM; LEAL, MAA; RIBEIRO, RLD. 2012. Produção de cebola orgânica em função do uso de cobertura morta e torta de mamona. Horticultura Brasileira 30: 549-552.

SEDIYAMA, MAN; SANTOS, MR; VIDIGAL, SM; SALGADO, LT. 2011. Produtividade e exportação de nutrientes em beterraba cultivada com cobertura morta e adubação orgânica. Revista Brasileira de Engenharia Agricola e Ambiental 15: 883-889.

SILVA, DMN. 2015. Cultivo de yacon em duas condições edafoclimáticas e épocas de plantio no sul do Espirito Santo. Alegre: CCAE/ UFES. 86p. (Ph.D. thesis).

SILVA, DMN; OLIVEIRA, FL; GRAZZIOTTI, PH; FÁVERO, C; QUARESMA, MAL. 2013. Cultivo de quiabeiro sobre cobertura viva de solo no Médio Jequitinhonha. Horticultura Brasileira 31: 450-456.

SILVA, FAS; AZEVEDO, CAV. 2006. A new version of the Assistat-Statistical Assistance software. In: WORLD CONGRESS ON COMPUTERS IN AGRICULTURE, 4. Anais... Orlando, USA: American Society of Agricultural Engineers. p.393-396.

TOSTES, MGV; VIANA, ML; GRANCIERI, M; LUZ, TCS; PAULA, H; PEDROSA, RG; COSTA, NMB. 2014. Yacon effects in immune response and nutritional status of iron and zinc in preschool children. Nutrition 30: 666-722.

VILHENA, SMC; CÂMARA, FLA; KADIHARA, ST. 2000. O cultivo do yacon no Brasil. Horticultura Brasileira 18: 5-8.

ZERAIK, ML; PEREIRA, CAM; ZUIN, VG; YARIWAKE, JH. 2010. Maracujá: um alimento funcional? Revista Brasileira de Farmacologia 20: 459-471. 